Article

\title{
Linking Food Democracy and Sustainability on the Ground: Learnings from the Study of Three Alternative Food Networks in Brussels
}

\author{
François Lohest ${ }^{1, *}$, Tom Bauler ${ }^{1}$, Solène Sureau ${ }^{2}$, Joris Van Mol ${ }^{2}$ and Wouter M. J. Achten ${ }^{2}$ \\ ${ }^{1}$ Institute for Environmental Management and Land-Use Planning, Center for Studies on Sustainable Development, \\ Université Libre de Bruxelles, 1050 Brussels, Belgium; E-Mails: frlohest@ulb.ac.be (F.L.), tbauler@ulb.ac.be (T.B.) \\ 2 Institute for Environmental Management and Land-Use Planning, Environmental Management, Society and Territory, \\ Université Libre de Bruxelles, 1050 Brussels, Belgium; E-Mails: ssureau@ulb.ac.be (S.S.), joris.van.mol@ulb.ac.be (J.V.M.), \\ wouter.achten@ulb.ac.be (W.A.) \\ * Corresponding author
}

Submitted: 4 April 2019 | Accepted: 7 July 2019 | Published: 28 October 2019

\begin{abstract}
The article explores and discusses, both conceptually and empirically, the exercise of food democracy in the context of three alternative food networks (AFNs) in Brussels, Belgium. It demonstrates that food democracy can be described as a "vector of sustainability transition". The argumentation is built on the results of a 3.5-year participatory-action research project that configured and applied a sustainability assessment framework with the three local AFNs under study. Firstly, the article presents a localized understanding of food democracy. Food democracy is defined as a process aiming to transform the current food system to a more sustainable one. This transformation process starts from a specific point: the people. Indeed, the three AFNs define and implement concrete processes of power-configuration to alter the political, economic, and social relationships between consumers and producers as well as between retailers and producers. Secondly, the article assesses and discusses how the three AFNs perform these practices of food democracy and what effects these have on the actors concerned. The assessment shows that the three AFNs distinguish themselves along a gradient of their transformative potential in terms of practices. However, this variation in their interpretation of food democracy does not translate into a gradient of performance.
\end{abstract}

\section{Keywords}

alternative food networks; food democracy; sustainability assessment; sustainability transition

\section{Issue}

This article is part of the issue "New Perspectives on Food Democracy" edited by Basil Bornemann (University of Basel, Switzerland) and Sabine Weiland (Université Catholique de Lille, France).

(C) 2019 by the authors; licensee Cogitatio (Lisbon, Portugal). This article is licensed under a Creative Commons Attribution 4.0 International License (CC BY).

\section{Introduction: Alternative Food Networks, Sustainability, and Democracy}

Alternative food networks (AFNs) are under deep scrutiny since they emerged as concrete attempts to counter the negative externalities of the dominant global and industrial food system (Deverre \& Lamine, 2010; Le Velly, 2016; Maye \& Kirwan, 2010; Tregear, 2011). Commonly, the concept of AFNs "cover[s] newly emerging networks of producers, consumers and other ac- tors that embody alternatives to the more standardized industrial mode of food supply" (Renting, Marsden, \& Banks, 2003, p. 394). Examples of AFNs include short food supply chains, solidarity purchasing groups, farmer's market, and community-supported agriculture or consumers food co-operatives and foods with a geographical indication of origin.

On the ground, AFNs are mainly alternative food distribution systems, their primary focus being to experiment with and drive the transition towards sustainabil- 
ity of the current food system (Kirwan, Ilbery, Maye, \& Carey, 2013; Maye \& Duncan, 2017; Rossi, 2017). A recent literature review states that AFNs intend to build sustainable food systems by way of three types of innovative practice (Forssell \& Lankoski, 2015). First, AFNs promote ecological ways of growing food by marketing and distributing high-quality foodstuffs. Positive impacts on the environment, especially on soils and biodiversity, as well as on human health, are expected. Second, AFNs experiment with new types of food chain configuration reducing the spatial and social distance between producers and consumers involving minimal geographical transport distances, minimal value chain length (number of intermediaries) and minimal informational distance. Socioeconomic impacts are projected, such as improved income for producers and stronger social ties between food chain actors, improving territorial/rural development (Praly, Chazoule, Delfosse, \& Mundler, 2014; Renting et al., 2003). Mutual trust is targeted, too, as well as ecological benefits from reduced food miles (Mundler \& Rumpus, 2012). Third, AFNs experiment with new governance schemes and reconfigure power relationships along the food chain. While the first two sets of innovative practices target ecological and socio-economic impacts, the third dimension directly addresses the issue of food democracy. Although AFNs could only choose one of these three archetypal sets of innovative activities, they generally combine two or all of them, with different intensities. This means that AFNs hold a core set of sustainability promises with which food democracy is intrinsically associated.

Introduced in the 1990s by Lang (1999), food democracy was precisely developed to describe such grassroots experiments, alternative to the global food system controlled by big companies and framed by the agricultural (production) agendas. The core idea of food democracy is then to give more power to all the actors involved in the food chain; it is a call for more consumer/citizen participation in the management and the control of the food system (Booth \& Coveney, 2015; Dubuisson-Quellier \& Lamine, 2008; Hassanein, 2003; Levkoe, 2006; Lockie, 2009; Renting, Schermer, \& Rossi, 2012; Wilkins, 2005). Similarly, Hassanein (2003) defined food democracy as a means for collective action, and more precisely as a pragmatic and gradual method for the transformation of the food system to sustainability. The concept of "civic food networks" equally emerged to designate AFNs as the "expression of the revitalized role of civil society-based governance mechanisms" and "a source of dynamism and innovation" (Renting et al., 2012, p. 297). From this specific point of view, the project of AFNs concerns the transformation of the food regime from a particular starting point: the people.

In this article, we argue that in the context of AFNs, food democracy mainly acts as a "vector of [sustainability] transition" (Chiffoleau, Millet-Amrani, \& Canard, 2016; Kropp, 2018; Rossi, 2017). It is a core set of innovative practices implemented by AFNs that reconfig- ure power relationships along the food chains they promote in order to build a more sustainable food system. If using a sustainability transition perspective (Geels \& Schot, 2007), this definition of food democracy allows AFNs to be linked to the developing concept of "transformative social innovation" defined as "a process of change in social relations, involving new ways of doing, organizing, framing and/or knowing, which challenge, alter and/or replace established (dominant) institutions in a specific socio-material context" (Haxeltine et al., 2016, p. 8). It means that AFNs have a high transformative potential linked to the new ways of organizing and governing the entire food chains they promote; this potential to transform sustainability relates to their practices of food democracy/democratic processes, and that is concerned with the power-relationships they configure.

However, the literature on AFNs remains unclear in identifying clearly and systematically how AFNs conceptualize, operationalize, and implement food democracy, and what effects are exerted on the actors/citizens involved. This article attempts to fill this gap and suggests giving specific content to food democracy in the context of AFNs daily sustainability practices. Based on the results of 3.5 years of participatory research (CosyFood, 2019) which configured and applied a sustainability assessment framework for local AFNs, this article conceptually and empirically explores the relationship between sustainability and democracy in the context of three AFNs in Brussels, Belgium. This article demonstrates how food democracy forms a cornerstone of the sustainability project of these AFNs but also that the idea of food democracy shapes a diversity of practices. Moreover, this article explores whether and how local AFNs in Brussels allow for the emergence and navigation of food democracy within their very own alternative practices.

The article is structured as follows. In the next section (Section 2), the research context is described, empirical materials, and method. We will focus on the participatory aspects of our research. In Section 3, the indicators linked to food democracy and the results are presented. The particular practices that promote the construction of food democracy will be described and discussed (Section 3.1), as well as the impacts of those processes on each AFN stakeholder (Section 3.2). In Section 4, based on the results, the link between food democracy and sustainability transformation is discussed. Section 5 presents the conclusions.

\section{Research Context and Empirical Materials}

This article is based on (a part of) the results of the CosyFood project. In this participatory-action research project, we worked for 3.5 years with three AFNs in Brussels. Each project partner (i.e., us, a university partner, and the three AFNs) was funded by the research program (1.5 full-time employees for the university partner and 1 full-time employee for each AFN partner). 


\subsection{The CosyFood Project: Partners and Goals}

The three AFNs involved in the CosyFood project are quite different. The first AFN is a brand (and partially a franchise) of neighbourhood organic shops with a cooperative status ("the organic shops" in the following sections). This AFN exclusively retails organic foodstuffs favouring local products and shorter supply chains. It started in 2013 with only one small shop. It is now (early 2019) a bigger cooperative network involving nine organic shops in Brussels. Total sales were around $€ 15.5$ million in 2017 and it employs around 100 staff.

The second AFN is a non-profit organization which networks solidarity purchasing groups for peasant agriculture ("the Gasap" in the following sections). Since 2008, organic local farmers deliver their products every (two) week(s) directly to ninety (in 2019) small groups of consumers. Every group organizes themselves to take collective care of the foodstuffs' distribution as well as financial operations. Each local farmer and each purchasing group is a legal member of the organization. The organization supports the system in multiple ways: the selection of farmers, organization of meetings between farmers and consumer groups, dissemination of the model. The Gasap receives a public subvention for sustaining these support activities. The total sales by the local farmers involved were around $€ 1.3$ million in 2017.

The third AFN is an online shop which exclusively sells local foodstuffs from organic or conventional small/medium-scale farmers and transformers ("the online shop" in the following sections). Farmers and food processors must participate in the weekly 2-hour distribution event. The digital tool provider, which is a startup located in France, manages the online shop centrally. However, at the local level, it is always a person who is in charge of configuring the network of producers and consumers, and of organizing and hosting the weekly distribution. For the Brussels case under study, it is a cooperative that hosts this configuring task. In 2017, sales were around $€ 0.5$ million.

To involve the three AFNs in the whole research process, the research methodology was built on the existing good practices for participatory-action research (Chevalier, Buckels, \& Bourassa, 2013) and participatory evaluation (Sébastien, Lehtonen, \& Bauler, 2017). The five people funded by the project together managed all of the research activities and considered themselves as equally skilled citizen-researchers, with a mutually recognized field expertise related to food chains and food sustainability. The goals of the project were as follows: 1) to configure a shared sustainability assessment framework for 2) assessing and comparing the impacts of the three AFNs on local sustainability and 3) to apply the content of the shared sustainability framework into specific sustainability improvement-tools for each AFN. This article is built on the results linked to the two first objectives, for which we gathered distinctive materials corresponding to particular methods.

\subsection{Materials and Method}

The first set of materials used in this article is the content of the sustainability assessment framework. This content has been co-constructed by the four project partners for nearly two years. To do this, the "principlecriteria-indicators" framework was used (Rey-Valette et al., 2008). By starting from a blank page, this method takes into account the actors' representations, values, beliefs, and knowledge. Concretely, a series of participatory workshops and co-creational activities were conducted with each type of AFN stakeholder: leaders and employees, producers, and consumers. By the end of the process, the sustainability assessment tool contained 14 sustainability principles, 55 sustainability criteria, and 105 indicators (the full framework with the detailed description of all principles is available in French at CosyFood, 2019).

The principles designate the most critical sustainability goals for the (alternative) food system. They reveal a shared and collective vision in terms of values, beliefs, and ethics. This vision embraces fundamental values of sustainability such as solidarity, economic viability, fairness and justice, sensitization and transparency, and of course elements regarding strong respect for the ecological limits of the planet. The criteria define the precisely elaborated conditions for respecting those principles in the context of a food network. The whole set of criteria represents a shared roadmap towards a sustainable (alternative) food system. It is important to mention that the three AFNs wanted to distinguish "performance criteria" from "practice criteria". Performance criteria designate "levels of performance" (e.g., the level of participation) that can be more or less defined as impacts. Practice criteria identify the concrete practices that AFNs have to implement to be able to perform at the desired level (e.g., promoting participation [or not] in the decision-making process). Finally, the indicators translate each criterion into precise measurements and allow them to assess whether AFNs conform to their roadmap. In Section 3.1, the criteria and indicators of food democracy identified for this article are presented and discussed.

The second set of materials used in this article is the data collected for the measurement of the identified food democracy indicators. This data was produced following a qualitative survey conducted between February and June 2018. Data was collected through anonymous online questionnaires with the relevant actors of each AFN (farmers, wholesalers if any, food processors, consumers) and consolidated with semi-structured interviews with three leading actors ("managers") in each AFN. The number of questionnaires sent varies in each AFN because they vary in terms of size (see Table 2 and its footnote).

Using these two sets of materials, the following sections of the article consist of, on the one hand, in an inductive re-construction and ex-post re-interpretation of 
a localized understanding of food democracy in the context of the three AFNs; an interpretation of the materials in the light of a food democracy perspective. On the other hand, the data collected by the survey allows assessment of whether the three AFNs conform to their understanding of food democracy, understood as a vector of transformation towards sustainability.

\section{Reconstructing Perspectives on Food Democracy in the Context of Three AFNs in Brussels}

\subsection{Food Democracy: Vector of Transition by Giving Back Power to the Food Chains Actors}

As mentioned in the introduction, food democracy as a concept was developed to promote and apprehend grassroots experiments such as AFNs that give back control and power to the actors involved in the food supply chains. Food democracy is about re-engaging citizens and food actors into the governance of the food sys- tem, which is currently wholly framed and structured by "state-market" interests and agendas (De Schutter, Mattei, Vivero-Pol, \& Ferrando, 2019). It also refers to a demand for more citizen participation in the management and control of the food system. Based on this, we consider that food democracy leads to transformation towards sustainability through the reconfiguration of power-relationships.

For this article and with these very generic and general considerations in mind, we scrutinized the whole set of sustainability criteria and indicators. We identified and selected 12 (of 55) criteria linked to the field of food democracy as broadly defined above: six performance criteria and six practice criteria. Subsequently, we linked 15 (of 105) indicators to the notion of food democracy as described in the introduction (see Table 1).

By analyzing the content of the 12 criteria and the 15 corresponding indicators, it is possible to reconstruct the vision of food democracy shared by the three AFNs involved in the project. This was done by connecting food

Table 1. Criteria and indicators linked to democracy.

\begin{tabular}{|c|c|c|}
\hline & Assessment criteria & Indicators \\
\hline \multirow[t]{9}{*}{ Practices } & Funding resources & A1. Ownership properties of the retailer/facilitator \\
\hline & \multirow[t]{2}{*}{ Participation in the decision-making process } & $\begin{array}{l}\text { A2. Existence of participative and/or cooperative } \\
\text { decision-making processes }\end{array}$ \\
\hline & & $\begin{array}{l}\text { A3. The formal/legal distribution of power in the } \\
\text { decision-making process }\end{array}$ \\
\hline & \multirow[t]{2}{*}{ Sensitization practices } & $\begin{array}{l}\text { B1. Existence of formal sensitization programs } \\
\text { for consumers }\end{array}$ \\
\hline & & $\begin{array}{l}\text { B2. Which information is offered to the consumers and } \\
\text { by which means }\end{array}$ \\
\hline & $\begin{array}{l}\text { Knowledge transmission and learning } \\
\text { processes }\end{array}$ & $\begin{array}{l}\text { B3. Existence of frequent and formal meetings between } \\
\text { producers and consumers }\end{array}$ \\
\hline & \multirow[t]{2}{*}{ Terms of trade } & C1. Level of pricing power for producers/suppliers \\
\hline & & C2. The basis for setting prices \\
\hline & $\begin{array}{l}\text { Competition management by the } \\
\text { retailer/facilitator }\end{array}$ & $\begin{array}{l}\text { C3. Commitment modalities between sellers } \\
\text { (producers/suppliers) and buyers (retailer or consumers) }\end{array}$ \\
\hline \multirow[t]{6}{*}{ Performances } & Level of participation of the stakeholders & $\begin{array}{l}\text { A4. Whether the stakeholders are satisfied with their } \\
\text { power and inclusion in the decision-making processes }\end{array}$ \\
\hline & $\begin{array}{l}\text { Quality of social relations between } \\
\text { stakeholders }\end{array}$ & $\begin{array}{l}\text { B4. Whether the producers/suppliers trust in the } \\
\text { reliability of the relationships with the retailer/facilitator }\end{array}$ \\
\hline & $\begin{array}{l}\text { Level of recognition of the work of the } \\
\text { producers/suppliers }\end{array}$ & $\begin{array}{l}\text { B5. Whether the supplier feels recognized and valued } \\
\text { for his/her work by the client }\end{array}$ \\
\hline & $\begin{array}{l}\text { Level of consumers' sensitization } \\
\text { about sustainable food and producers' } \\
\text { daily realities }\end{array}$ & $\begin{array}{l}\text { B6. Whether the consumers feel more } \\
\text { and more aware and conscious about the sustainability } \\
\text { of food systems and producers' labor conditions }\end{array}$ \\
\hline & $\begin{array}{l}\text { Level of the economic viability } \\
\text { of producers }\end{array}$ & $\begin{array}{l}\text { C4. Level of monthly income in regards to the minimal } \\
\text { local income to live }\end{array}$ \\
\hline & Affordability & $\begin{array}{l}\text { C5. Level of feeling about economic affordability } \\
\text { (consumers) }\end{array}$ \\
\hline
\end{tabular}


democracy to their overall common sustainability framework. Regarding this, food democracy for them does not solely represent an isolated "fourth pillar" of sustainability. It instead appears as a transversal starting point for diverse practices aiming to reach a certain global level of sustainability. Indeed, when scrutinizing the criteria and indicators linked to food democracy listed in Table 1, the interdependence between practices and performances can quite easily be observed. Also, it can be seen that the identified criteria and indicators address the idea of power-(re)configuration. In this respect, the practices that give back power to the actors involved are envisioned along three dimensional comprehensions of power: political power, understood as the "power to decide and to participate in the decision-making process" (indicators labelled with an A in Table 1); power, in terms of social resources, understood as gaining capacity through learning and building a confident social network (indicators labelled with a B), and economic power understood as gaining commercial and economic capacity (indicators labelled with a C).

Furthermore, the above selection of criteria and indicators illustrates that the three AFNs want to assert explicitly that the three different dimensions of power are interrelated. As we observed during the research process, the three AFNs are aware that, for example, giving a formal right to vote to a producer to participate in the decision-making process does not necessarily mean that he/she will use it. For this producer, gaining the legal power to configure the AFNs functioning (political power) does not mean either that they will be free from all constraints when they set the prices of their foodstuffs (economic power) or that they will feel part of the AFN community (social power). Though, for the three AFNs which developed the sustainability framework, as far as food democracy is also part of the general sustainability endpoint, the ideal target is that all the conditions linked to democracy and listed in Table 1 must occur. In their perfect world, sustainability would only be fully achieved if those three sets of power-configuration practices arose and if they led to the expected performance.

These elements illustrate the result of a Brusselscontextualized inquiry about the grassroots significance of food democracy, understood in relationship to food sustainability. Moreover, we assert that the participatory process has produced and defined a formal set of food democratization practices. These practices appear as necessary conditions and vectors of sustainability. So, it becomes now possible to extend and give concrete content to the notion of "food democracy". The sustainability assessment framework includes the contextualized conditions (the criteria) for building food democracy; at the same time, it offers a way to assess the effectiveness of its implementation and related effects (the indicators).

Finally, based on the criteria and indicators they coconstructed during the CosyFood project, it is evident that the three AFNs involved are, at least in terms of intentions, democracy-led and aware of the democracy issues around food. The food democracy elements they have put on the table is empirical proof of their awareness of the need to implement participatory processes and more balanced power-configurations within their daily practices of food distribution and consumption. Such shared attention to food democracy illustrates that the grassroots actors are already on their way to building a more democratic, and as a result, a more sustainable food system. However, the following section explores in more detail what effects each AFN has concerning food democracy.

\subsection{Food Democracy on the Ground: Food Democracy Performances in 3 Contextualized AFNs}

The results compiled in Table 2 show if and to what extent the three AFNs implement (some of) the identified practices for building food democracy and the effect of these on their performance.

The first category of indicators relates to the configuration of political power within the food chains. The results reveal that when the stakeholders involved were asked if they were satisfied with their political power, the average satisfaction score (Indicator A4) is very similar for each of the three AFNs. This even though the daily implemented practices (Indicators A1 to A3) vary between the three AFNs.

The online shop is hosted by a co-operative recognized by the Belgian Centre National de la Coopération, which means, among other things, that each member gets one vote at the Annual General Meeting (AGM). Formally, the consumers and farmers who invested and bought some shares get an equal power in the decisionmaking process. Informally, in this AFN, the general assembly tends to validate decisions and choices made by the project manager. The project manager thus has the power to decide about the day-to-day practices as far as informal consultations of AFNs members nurture the most important choices.

Even though they are called "co-operative", the organic shops are not recognized as such because they do not respect all basic principles of co-operatives (e.g., mechanisms to limit the power of controlling partners and distribution of dividends). Indeed, at the AGM, the members' voting power depends on the number of economic shares owned. Because a few investors own the majority of shares, the final decisions belong to them, and they are more potent than the other "co-op members" (consumers, farmers, suppliers, managers, workers). Nevertheless, they have a more balanced power when it comes to the daily management of the supermarkets. At the level of the board, investors cannot force a decision even if they were to join together and oppose all the other represented categories of cooperators.

The Gasap is a non-profit organization. This official status implies that each member at the general meeting must have equal voting power ("one man, one vote"). However, in the way that the organization performs 
Table 2. Measurement of the indicators linked to food democracy in three Brussels-based AFNs.

\begin{tabular}{|c|c|c|c|c|}
\hline Power type & Indicators & Organic shops & Gasap & Online shop \\
\hline \multirow[t]{3}{*}{$\begin{array}{l}\text { Political power- } \\
\text { configuration } \\
\text { practices }\end{array}$} & $\begin{array}{l}\text { A1. Ownership properties } \\
\text { of the retailer/facilitator }\end{array}$ & $\begin{array}{l}\text { Non-recognized } \\
\text { co-operative; } \\
\text { ownership by } \\
\text { investors }\end{array}$ & $\begin{array}{l}\text { Nonprofit } \\
\text { organization, no } \\
\text { capital ownership }\end{array}$ & $\begin{array}{l}\text { Host within a } \\
\text { recognized } \\
\text { co-operative; } \\
\text { ownership by } \\
\text { cooperators }\end{array}$ \\
\hline & $\begin{array}{l}\text { A2. Existence of } \\
\text { participative and/or } \\
\text { cooperative } \\
\text { decision-making processes }\end{array}$ & $\begin{array}{l}\text { Structural, formal } \\
\text { participative } \\
\text { decision-making } \\
\text { processes }\end{array}$ & $\begin{array}{l}\text { Structural, formal } \\
\text { participative } \\
\text { decision-making } \\
\text { processes }\end{array}$ & $\begin{array}{l}\text { Informal } \\
\text { participation and } \\
\text { consultation }\end{array}$ \\
\hline & $\begin{array}{l}\text { A3. The formal/legal } \\
\text { distribution of power in the } \\
\text { decision-making process }\end{array}$ & One share, one vote & $\begin{array}{l}\text { One member (group } \\
\text { or farmer), one vote }\end{array}$ & $\begin{array}{l}\text { One member } \\
\text { (farmer or } \\
\text { consumer), one vote }\end{array}$ \\
\hline $\begin{array}{l}\text { Political power- } \\
\text { configuration } \\
\text { performances }\end{array}$ & $\begin{array}{l}\text { A4. Whether the } \\
\text { stakeholders are satisfied } \\
\text { with their power and } \\
\text { inclusion in the } \\
\text { decision-making processes }\end{array}$ & Average $3.2 / 5$ & Average $3.6 / 5$ & Average $3 / 5$ \\
\hline \multirow[t]{3}{*}{$\begin{array}{l}\text { Social power- } \\
\text { configuration } \\
\text { practices }\end{array}$} & $\begin{array}{l}\text { B1. Existence of formal } \\
\text { sensitization programs for } \\
\text { consumers }\end{array}$ & No & $\begin{array}{l}\text { Yes. One employee is } \\
\text { dedicated to this. } \\
\text { Specific "discussions" } \\
4 \text { times a year for the } \\
\text { members }\end{array}$ & No \\
\hline & $\begin{array}{l}\text { B2. Which information is } \\
\text { offered to the consumers } \\
\text { and by which means }\end{array}$ & $\begin{array}{l}\text { Label, newsletter, } \\
\text { digital social } \\
\text { networks }\end{array}$ & $\begin{array}{l}\text { Visits on farms, Label, } \\
\text { dedicated } \\
\text { communication, } \\
\text { participative quality } \\
\text { control, free } \\
\text { conversations with } \\
\text { farmers during the } \\
\text { distribution }\end{array}$ & $\begin{array}{l}\text { Dedicated } \\
\text { communication, } \\
\text { open discussions } \\
\text { with farmers during } \\
\text { the distribution }\end{array}$ \\
\hline & $\begin{array}{l}\text { B3. Existence of frequent } \\
\text { and formal meetings } \\
\text { between producers and } \\
\text { consumers }\end{array}$ & No & $\begin{array}{l}\text { Yes, every (two) } \\
\text { week(s) }\end{array}$ & Yes, weekly \\
\hline \multirow[t]{3}{*}{$\begin{array}{l}\text { Social power- } \\
\text { configuration } \\
\text { performances }\end{array}$} & $\begin{array}{l}\text { B4. Whether the } \\
\text { producers/suppliers trust in } \\
\text { the reliability of the } \\
\text { relationships with the } \\
\text { retailer/facilitator }\end{array}$ & Average $4.1 / 5$ & Average $4 / 5$ & Average $4.4 / 5$ \\
\hline & $\begin{array}{l}\text { B5. Whether the supplier } \\
\text { feels recognized and valued } \\
\text { for his/her work by his } \\
\text { clients }\end{array}$ & Average $3.4 / 5$ & Average $4.1 / 5$ & Average $4.5 / 5$ \\
\hline & $\begin{array}{l}\text { B6. Whether the consumers } \\
\text { feel more and more aware } \\
\text { and conscious about the } \\
\text { sustainability of food } \\
\text { systems and producers' } \\
\text { labor conditions }\end{array}$ & Average $3.7 / 5$ & Average $4.2 / 5$ & Average $4.3 / 5$ \\
\hline
\end{tabular}


Table 2. (Cont.) Measurement of the indicators linked to food democracy in three Brussels-based AFNs.

\begin{tabular}{|c|c|c|c|c|}
\hline Power type & Indicators & Organic shops & Gasap & Online shop \\
\hline \multirow[t]{3}{*}{$\begin{array}{l}\text { Economic } \\
\text { power- } \\
\text { configuration } \\
\text { practices }\end{array}$} & $\begin{array}{l}\text { C1. Level of pricing power } \\
\text { for producers/suppliers }\end{array}$ & $\begin{array}{l}\text { Negotiation with } \\
\text { suppliers, no } \\
\text { negotiation with } \\
\text { farmers }\end{array}$ & High & High \\
\hline & $\begin{array}{l}\text { C2. The basis for setting } \\
\text { prices }\end{array}$ & $\begin{array}{l}94 \% \text { of farmers who } \\
\text { sell directly to the } \\
\text { AFN set prices based } \\
\text { on production costs }\end{array}$ & $\begin{array}{l}47 \% \text { of farmers set } \\
\text { prices based on } \\
\text { production costs }\end{array}$ & $\begin{array}{l}95 \% \text { of farmer set } \\
\text { prices based on } \\
\text { production costs }\end{array}$ \\
\hline & $\begin{array}{l}\text { C3. Commitment modalities } \\
\text { between sellers } \\
\text { (producers/suppliers) and } \\
\text { buyers (retailer or } \\
\text { consumers) }\end{array}$ & No commitment & Mutual commitment & No commitment \\
\hline \multirow[t]{2}{*}{$\begin{array}{l}\text { Economic } \\
\text { power- } \\
\text { configuration } \\
\text { performances }\end{array}$} & $\begin{array}{l}\text { C4. Level of monthly } \\
\text { income in regards to the } \\
\text { minimal local income to live }\end{array}$ & $\begin{array}{l}65 \% \text { of farmers have } \\
\text { monthly income } \\
\text { higher than the } \\
\text { minimal income }\end{array}$ & $\begin{array}{l}52 \% \text { of farmers have } \\
\text { monthly income } \\
\text { higher than the } \\
\text { minimal income }\end{array}$ & $\begin{array}{l}71 \% \text { of farmers have } \\
\text { monthly income } \\
\text { higher than the } \\
\text { minimal income }\end{array}$ \\
\hline & $\begin{array}{l}\text { C5. Level of feeling about } \\
\text { economic affordability } \\
\text { (consumers) }\end{array}$ & Average $3 / 5$ & $4 / 5$ & $3.7 / 5$ \\
\hline
\end{tabular}

Notes: For the organic shops, the questionnaires were sent to seven wholesalers and six farmers and eight transformers who deliver the stores directly. Together, these actors represent $50 \%$ of the total supply of the organic shops. The response rate was $95 \%$ : All the wholesalers and farmers responded and seven of the eight transformers. For the indicators regarding consumers, 122 consumers voluntary responded to the survey, online or on paper. For the Gasap, the questionnaires were sent to 20 farmers and three transformers, in other words, all the network providers. The global response rate is $73 \%$ : 16 farmers and one transformer. In this AFN, 186 consumers answered the online survey. For the online shop, we went the questionnaires to all the providers (17 farmers and four transformers), and only one farmer did not respond. So, the response rate was $90 \% .76$ consumers answered the online survey. In the case of performance criteria and corresponding indicators, the respondents were asked to evaluate the theme/subject at stake on a satisfaction scale, from 1 (not satisfied at all) to 5 (very satisfied). The final scores, as compiled in Table 2, refer to the average score of the all concerned actors' level of satisfaction. In the case of practice criteria and corresponding indicators, the results summarize the qualitative data that was gathered.

day-to-day, the board takes all the important decisions, together with the employees, while the AGM approves the annual budget and the annual action plan.

As a significant innovation on the path towards greater levels of food democracy, we see that every type of actor in each of the AFNs gets an opportunity to participate in the decision-making process. Providers (farmers, transformers, wholesalers) and consumers hold an influence over the configuration of the system and the way it operates. In the case of the organic shops, the formal power is less balanced between actors. For now, a few investors own most of the capital and have the last word. However, in the cases of the Gasap and the online shop, if the distribution of political power seems to be fairer and better balanced, the main decisions are taken by board members, employees, volunteers, or manager(s).

However, in terms of practices, the legal position and the ownership configuration of the AFNs are still only symbolic signals about the formal opportunity to participate given to the actors in the value chain. Indeed, each AFN can operate formal and informal participative processes, whatever its legal status and ownership property.
In this way, the organic shops and the Gasap have implemented structural participative decision-making processes, contrary to the online shop, which consults value chain actors only informally. Simultaneously, the measurements of the performance show that even though each AFN implements different practices, this makes no difference in terms of the effects observed. Within the three political power-configurations, the actors (farmers and suppliers in our data) do feel involved but are not completely satisfied with their involvement.

The second category of indicators relates to social power. The central insight resulting from the assessment concerns the direct contact between farmers and consumers, a characteristic which differentiates the organic shops from the two other AFNs. In terms of performance, the results show that when there are frequent direct meetings between farmers and consumers, as in the Gasap and the online shop, the farmers feel more recognized for their work (Indicator B5).

However, regarding the two other scores, the differences between the three AFNs are not significant. Firstly, concerning sensitization (Indicator B6), the frequent di- 
rect meetings between farmers and consumers should help to make consumers more involved and aware of sustainability and agricultural conditions. However, this does not produce significantly different effects. This practice is the leading information channel about production processes and the quality of foodstuffs used by the Gasap and the online shop. The organic shops use more delegation practices such as labels and passive information, which seem to perform equally. Secondly, regarding the level of trust in the reliability of the relationship between providers and retailers/facilitators, there is little evidence of a difference. The Gasap has the lowest score in terms of trust and reliability. This result is puzzling; indeed, the Gasap implements the most coherent and complete program of sensitization in comparison to the other two. It also gives priority to the building of ties between categories of actors. In summary, as in the case of the decision-making processes, different practices generate no significant difference in terms of performances, except maybe for the farmers' quest for recognition of their work.

Social ties and relationships between actors could also be associated with power dynamics in economic terms. If looking at commercial relationships (Indicator C1), none of the AFNs negotiate the prices of the foodstuffs with the farmers and the organic shops negotiate solely when the supplier is a wholesaler. The Gasap in the only one that operates with a mutual commitment between the buyers (the consumers directly) and the farmers (Indicator C3). However, if relating this to the scores concerning the farmers' level of economic viability (Indicator (4), and the ratings about the freedom to set prices based on production costs, we identify a paradox for the Gasap. Indeed, mutual commitment to a fair price is formally much stronger than in the two other AFNs, but it does not lead to economic viability for farmers. Moreover, prices seem to be implicitly constrained by this mutual commitment because farmers do not dare to increase them. This situation contrasts with the case in the online shop: More farmers are profitable and are able to set prices based on their real production costs. Moreover, last but not least, the scores for the three AFNs regarding affordability are positive. A big dilemma remains: how to generate increased profitability for farmers while maintaining affordability for consumers.

\section{Food Democracy as a Vector Sustainability Transformation: Three Gradients of Transformative Potential}

If we return to the concept and definition of "transformative social innovation", we could say that the three AFNs distinguish themselves by their position along a gradient of their transformative potential. At one end of the axis, the organic shops implement the least stringent practices for each category of power-configuration. At the other end of the axis, the Gasap has the most ambitious targets and appears the most coherent system: deep democratic processes, lots of initiatives to reconnect individuals, especially farmers and consumers, as well as mutual economic commitment. Between these two AFNs, the online shop operates a more or less hybrid configuration.

Indeed, in terms of food democracy, the organic shops are only able to alter and challenge the dominant food system through their governance processes and practices, tending to reproduce the mainstream methods of organizing economic relationships and social ties. The online shop goes one step further: its transformative potential appears in the food chain's governance. Most of the democratic practices are informal, but it seems to perform well, especially if we look at the second category of indicators, regarding the social ties that are developed. However, this AFN is not transformative in terms of the configuration of its economic exchanges because of the mainstream market rules. The Gasap makes one more significant step beyond this. This AFN tries to alter the dominant regime through the governance of its chain. It builds solidarity through a community of people and implements disruptive commercial relationships between actors. Then, the Gasap holds the most potential to enact a radical version of transformation, because it is the most challenging to the dominant regime in each category of power-configuration.

Considering food democracy as a "vector of transition towards sustainability", the distinctive deepness of the transformative practices implemented by the three AFNs could have led to some differences in terms of performance. However, as we can see, none of the three AFNs performs in a perfectly democratic way. The observed and measured effects of the three distinctive power-configurations do not distinguish the three AFNs in terms of their performance, except for profitability where there is a more distinctive score. We may explain this constatation by the fact that the actors who responded in the survey are very diverse. It means that they could participate in each AFN for various reasons due to their diverse backgrounds. For example, the farmers' profiles are very distinctive, in terms of activity, size, means of production (e.g., manual vs. motorized), or longevity.

Of course, these explanations need more investigation. However, in the end, the results further contribute to illustrating that each AFN achieves at least a part of its objectives and generates (positive) effects on the actors who are involved. In this sense, the three categories of power-configuration processes can clearly label the three AFNs as an alternative to the mainstream regarding food democracy. They are all participative, formally as well as informally. So, if we look at the broader situation for the sustainability of the Brussels food system/regime, the results tend to show that the three AFNs participate in the transformation of the current food system, despite different transformative potentials (more or less stringent) but also despite their having different scales of activity. In the context of the broader field of research on 
sustainability transition, this assessment leads to further discussion and reflection on how coordinating and upscaling a diversity of food democracy practices can contribute to food sustainability.

\section{Conclusions}

The article showed that the three AFNs conceptualize and define food democracy as the way to reach some sustainability goals, mainly in governance and socioeconomic terms. In this respect, AFNs connect their daily practices and normative beliefs to the sustainability transition approach. Our participatory sustainabilityfocused assessment approach allowed us to reconstruct a grounded and socially constructed "vision" of food democracy that the three grassroots AFNs share in common. The identified criteria and indicators illustrate this vision and show a rather pragmatic relationship between food democracy and sustainability. Powerconfigurations need to transform, and new ways of organizing must be implemented to achieve sustainability goals. Democracy dimensions as such are part of the sustainability landscape but are also part of the pathway to more sustainable practice. Food democracy is a means for collective and transformative action. It consists of a set of processes that give more power to the actors involved in the food chains, at the three political, social, and economic levels. The authors proposed in this article to provide concrete and operational content to the concept of food democracy that can surely open new empirical research and investigations.

Furthermore, the article brings to the fore a new proposal that helps to assess aspects of food democracy practices in the context of AFNs. The set of criteria and indicators opens an interesting analytical tool around the three kinds of power-configuration processes at stake. Regarding this, the article fills a gap in the literature on food democracy and AFNs. It gives and proposes a concrete but potentially generic content to the concept of food democracy that as a result becomes more useable. Moreover, in terms of methodology and discussion, the developed analytical/assessment tool allows discussion of the potential interdependence between the three categories. For example, could it be possible for the organic shops to change their economic (commitment) practices, regarding their commercial scale and model, to achieve more direct contacts and learning between farmers and consumers?

Finally, the results illustrate that, in the context of a sustainability project, none of the three grassroots experiments are perfect, although they all achieved some great results, whatever the practices involved. On this basis, we classify the thee AFNs as transformative social innovations although they have different potentials for transformation.

However, our results appeal for more investigation. Firstly, it would be interesting to repeat the same process in other places to compare the visions of food democracy and food sustainability in the context of unconnected AFNs in terms of localization. Secondly, more detailed and empirical research should be conducted regarding the relationship between AFNs as social innovations which merely constitute a "niche", and the broader food "regime" (Seyfang \& Longhurst, 2013) at a regional or national level. Indeed, even if our article shows promising results about the effects of food democracy processes on the actors and individuals, it still lacking in the measures and explanations offered about how these transformations could lead to the transition of the regional food system.

\section{Acknowledgments}

The authors wish to express gratitude to the three AFNs they worked with during this 3.5-year research project, especially the employees and volunteers dedicated to the CosyFood project: Aurélie Labarge, Julie Minne, Isadora Meersseman, Christophe Nothomb, Florian Delespesse, and Camille Latin.

\section{Conflict of Interests}

The authors declare no conflict of interests.

\section{References}

Booth, S., \& Coveney, J. (2015). Food democracy: From consumer to food citizen. Singapore: Springer.

Chevalier, J., Buckels, D. J., \& Bourassa, M. (2013). Guide de la recherche-action, la planification et l'évaluation participatives [Guide to participatory action research, planning and evaluation]. Ottawa: SAS2 Dialogue.

Chiffoleau, Y., Millet-Amrani, S., \& Canard, A. (2016). From short food supply chains to sustainable agriculture in urban food systems: Food democracy as a vector of transition. Agriculture, 6(4), 57.

CosyFood. (2019). CosyFood. Action Co-Create. Retrieved from http://www.cocreate.brussels/CosyFood-

De Schutter, O., Mattei, U., Vivero-Pol, J. L., \& Ferrando, T. (2019). Food as commons: Towards a new relationship between the public, the civic and the private. In J. S. Vivero-Pol, T. Ferrando, O. De Schutter, \& U. Mattei, Routledge handbook of food as a commons (pp. 372-395). London and New York, NY: Routledge.

Deverre, C., \& Lamine, C. (2010). Les systèmes agroalimentaires alternatifs: Une revue des travaux anglophones en sciences sociales [Alternative agri-food systems: A review of english-language social science works]. Économie Rurale: Agricultures, Alimentations, Territoires, 2010(317), 57-73.

Dubuisson-Quellier, S., \& Lamine, C. (2008). Consumer involvement in fair trade and local food systems: Delegation and empowerment regimes. GeoJournal, 73(1), 55-65.

Forssell, S., \& Lankoski, L. (2015). The sustainability 
promise of alternative food networks: An examination through alternative characteristics. Agriculture and Human Values, 32(1), 63-75.

Geels, F. W., \& Schot, J. (2007). Typology of sociotechnical transition pathways. Research Policy, 36(3), 399-417.

Hassanein, N. (2003). Practicing food democracy: A pragmatic politics of transformation. Journal of Rural Studies, 19(1), 77-86.

Haxeltine, A., Avelino, F., Pel, B., Kemp, R., Dumitru, A., Longhurst, N., . . Strasses, T. (2016). TRANSIT WP3 deliverable D3.3-A second prototype of TSI theory (Grant agreement No. 613169). Rotterdam: Transformative Social Innovation Theory. Retrieved from http://www.transitsocialinnovation.eu/resourcehub/transit-wp3-deliverable-d33-a-secondprototype-of-tsi-theory-deliverable-no-d33

Kirwan, J., Ilbery, B., Maye, D., \& Carey, J. (2013). Grassroots social innovations and food localisation: An investigation of the local food programme in England. Global Environmental Change, 23(5), 830-837.

Kropp, C. (2018). Urban food movements and their transformative capacities. The International Journal of Sociology of Agriculture and Food, 24(3), 413-430.

Lang, T. (1999). Food policy for the 21st century: Can it be both radical and reasonable? In M. Koc, R. MacRae, L. J. Mougeot, \& J. Welsh (Eds.), For hunger-proof cities: Sustainable urban food systems. (pp. 216-224). Ottawa: International Development Research Centre.

Le Velly, R. (2016). Sociologie des systèmes alimentaires alternatifs: Une promesse de différence [Sociology of alternative food systems: A promise of difference]. Paris: Presses des Mines.

Levkoe, C. Z. (2006). Learning democracy through food justice movements. Agriculture and Human Values, 23(1), 89-98.

Lockie, S. (2009). Responsibility and agency within alternative food networks: Assembling the "citizen consumer". Agriculture and Human Values, 26(3), 193-201.

Maye, D., \& Duncan, J. (2017). Understanding sustainable food system transitions: Practice, assessment and governance. Sociologia Ruralis, 57(3), 267-273.

Maye, D., \& Kirwan, J. (2010). Alternative food networks.
Sociology of Agriculture and Food, 20, 383-389.

Mundler, P., \& Rumpus, L. (2012). The energy efficiency of local food systems: A comparison between different modes of distribution. Food Policy, 37(6), 609-615.

Praly, C., Chazoule, C., Delfosse, C., \& Mundler, P. (2014). Les circuits de proximité, cadre d'analyse de la relocalisation des circuits alimentaires [Short food supply chains, a framework for analysing the relocation of food chains]. Géographie, Économie, Société, 16(4), 455-478.

Renting, H., Marsden, T. K., \& Banks, J. (2003). Understanding alternative food networks: Exploring the role of short food supply chains in rural development. Environment and Planning A, 35(3), 393-411.

Renting, H., Schermer, M., \& Rossi, A. (2012). Building food democracy: Exploring civic food networks and newly emerging forms of food citizenship. International Journal of Sociology of Agriculture and Food, 19(3), 289-307.

Rey-Valette, H., Clément, O., Aubin, J., Mathé, S., Chia, E., Legendre, M., ... Lazard, J. (2008). Guide to the coconstruction of sustainable development indicators in aquaculture. Montpellier: EVAD.

Rossi, A. (2017). Beyond food provisioning: The transformative potential of grassroots innovation around food. Agriculture, 7(1), 6.

Sébastien, L., Lehtonen, M., \& Bauler, T. (2017). Introduction: Les indicateurs participatifs tiennent-ils leurs promesses? [Introduction: Are participatory indicators keeping their promise?]. Participations, 2(18), 9-38.

Seyfang, G., \& Longhurst, N. (2013). Desperately seeking niches: Grassroots innovations and niche development in the community currency field. Global Environmental Change, 23(5), 881-891.

Tregear, A. (2011). Progressing knowledge in alternative and local food networks: Critical reflections and a research agenda. Journal of Rural Studies, 27(4), 419-430.

Wilkins, J. L. (2005). Eating right here: Moving from consumer to food citizen. Agriculture and Human Values, 22(3), 269-273.

\section{About the Authors}

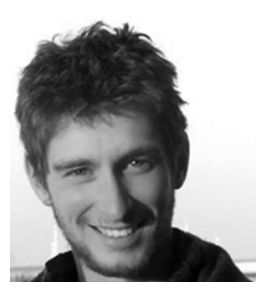

François Lohest, a Political Scientist by training (MSc 2009), has been a researcher at the Université Libre de Bruxelles since 2016. A former organic vegetable producer, he is now involved in research in the field of sustainability transitions, mainly regarding alternative food chains, food governance, and the upscaling of grassroots innovations. 


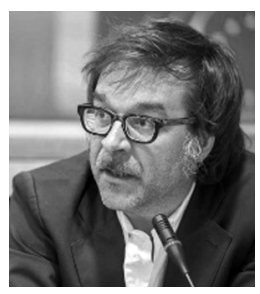

Tom Bauler (Prof.), an Ecological Economist leaning towards Science, Technology \& Society studies (STS), holds the Chair "Environment \& Economy" at the Université Libre de Bruxelles. Tom explores the roles of policy instruments and tools for environmental policy. Emphasis is given to questions relating to the place, insertion, use and impact of policy dynamics, discourses, instruments, and tools (e.g., indicators, scenario exercises, policy concepts).

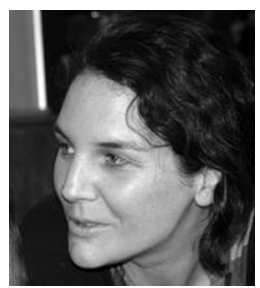

Solène Sureau is a PhD student at the Institute for Environmental Management and Land-Use Planning, Université Libre de Bruxelles. Her research focuses on the assessment of social and socio-economic impacts of Alternative Food Networks and the methodological development of social life cycle assessment (S-LCA). She holds a master's degree in Macroeconomics (Université de Strasbourg, 2007) and Environmental Management (Université Libre de Bruxelles, 2014).

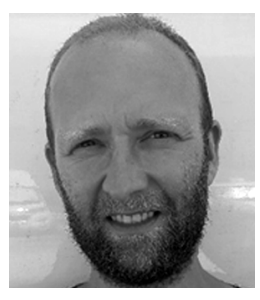

Joris Van Mol has been working on monitoring and evaluation in both public and private sector settings for over 10 years. He's been concentrating mainly on issues related to food and agriculture, with particular attention to social dimensions. Initially, his work focused on the position of smallholder farmers in the South and their integration in globalized value chains. Gradually, he became interested in the sustainability promise of more locally embedded alternative food systems. He is currently focusing on the role and contribution of reporting systems in the transition to a more sustainable economy.

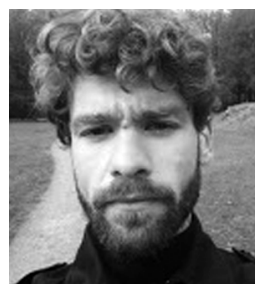

Wouter M. J. Achten, a Bio-Science Engineer by training (MSc 2005, PhD 2010), has been Professor of Environmental Impact Management at the Université Libre de Bruxelles since 2013. He is active on methodological and applied research in the field of sustainability science, mainly focusing on life cycle thinking tools. He hosts methodological research on land-use LCA, life cycle sustainability assessment, social LCA, input-output LCA, territorial LCA, consequential LCA, and currently applies this in the fields of agricultural production, bio-products, circular economy, waste management, and forestry. 